\title{
Effect of Leadership, Motivation, and Work Discipline on Employee Performance at PT. Aneka Gas Industri Tbk., North Sumatra Region
}

\author{
Wiwin $^{1}$, Hendra Nazmi ${ }^{2}$, Sylvi Febiola ${ }^{3}$, Henny $^{4}$ \\ ${ }^{1,2,3,4}$ Universitas Prima Indonesia, Indonesia \\ Corresponding Author: Hendra Nazmi
}

\begin{abstract}
The phenomenon of decreasing employee performance, leadership in the company, employee motivation that is still not good, and employee work discipline that has not been implemented properly by employees. The purpose of this study was to examine and analyze the influence of leadership, motivation, work discipline on employee performance at PT. Aneka Gas Industri Tbk., North Sumatra Region. The sampling technique in this study used simple random sampling using the Slovin formula in determining the sample. The number of samples in this study was 175 people. The results showed partially, the leadership variable shows a positive and significant effect on employee performance at PT. Aneka Gas Industri Tbk., North Sumatra Region, motivation shows a positive and significant effect on employee performance at PT. Aneka Gas Industri Tbk., North Sumatra Region, work discipline shows a positive and significant effect on employee performance at PT. Aneka Gas Industri Tbk., North Sumatra Region. In testing the data analysis simultaneously, the variables of leadership, motivation and work discipline shows a significant effect on employee performance at PT. Aneka Gas Industri Tbk., North Sumatra Region.
\end{abstract}

Keywords: Leadership, Motivation, Work Discipline, Employee Performance

\section{INTRODUCTION}

Companies in North Sumatra as well as in Indonesia are facing increasingly fierce business competition. One of them is
Human Resources; Human Resources that are getting better can also make a good contribution to the company.

PT. Aneka Gas Industri Tbk., is a company engaged in supplying gases such as air gases (oxygen, nitrogen and argon), synthetic gases, fuel gases, rare gases, sterilization gases, refrigerant gases and electronic gases. PT. Aneka Gas Industri Tbk. (AGI) also supplies mixed, specialty and medical gases as well as equipment and installation services. AGI products have a wide range of applications and are used by a wide range of industries including medical, metallurgy, energy, infrastructure and others.

Employee performance is the result of work owned by employees in carrying out their work. The problem of employee performance can be seen from the decline in income experienced by the company in the last 1 year. From the income data, it can be seen that the amount of income in the company tends to decrease from time to time. The decline in income shows a decrease in the performance of employees in the company at this time.

Leadership is the ability contained within a person to be able to influence others or guide certain parties to achieve a goal. In the problem of leadership in the company, the leader who is often absent due to important business makes supervision to subordinates less. Lack of supervision by superiors makes various mistakes work in various divisions. What is suspected to be 
the problem of lack of leadership is the leadership's ability to direct employees to carry out work, the leadership's ability to make the right decisions for the problems at hand, the unequal division of work, the lack of trust given by the leadership to employees to make decisions.

Motivation is the provision of work enthusiasm to employees in carrying out their work. The problem of motivation in the company is the lack of employee motivation due to high working hours, salary increases that are not obtained even though they have worked for a long time, unclear career development because the company only prioritizes senior employees, bonuses and incentives are often received late. In addition, leaders who are not close to employees make employee work motivation less good at work.

Work discipline is the willingness of employees to follow the regulations in the company. In terms of discipline in the company, employees often violate regulations such as being late for work, absent for no apparent reason, eating in the working room, disobeying the leadership's orders. This shows that the current work discipline in the company is not good.

The phenomenon of decreasing employee performance, leadership in the company, employee motivation that is still not good, and employee work discipline that has not been implemented properly by employees.

The purpose of this study was to examine and analyze effect of leadership, motivation, work discipline on employee performance at PT. Aneka Gas Industri Tbk., North Sumatra Region.

\section{LITERATURE REVIEW Leadership}

According to Nawawi (2011:15), states that leadership is the behavior or method chosen and used by leaders in influencing the thoughts, feelings, attitudes and behavior of members of the organization or their subordinates.
According to Edison et al. (2016:89), leadership is the way the leader acts and or how he influences his members to achieve certain goals.

According to Feriyanto and Shyta (2015:95), leadership basically implies an embodiment of the behavior of a leader, which concerns his ability to lead.

It can be concluded that leadership is a form of behavior from a leader in order to govern and influence subordinates to carry out and carry out various directions given to him.

\section{Motivation}

According to Gray in Winardi (2012:72), interpreting motivation as the result of a number of processes that are internal or external to an individual, which causes an attitude of enthusiasm in carrying out certain activities.

According to Sedarmayanti (2014:233), motivation is a willingness to spend a high level of effort towards organizational goals conditioned by the ability of that effort to meet individual needs.

According to Feriyanto and Shyta (2015:71), motivation is a process that explains the intensity, direction, and persistence of individuals to achieve their goals.

It can be concluded that motivation is an effort to provide encouragement in order to support increasing morale in the company at this time.

\section{Work Discipline}

According to Hasibuan (2014:64), work discipline is an attitude of awareness and willingness of employees to obey all the rules and norms that apply within a company.

According to Rivai and Sagala (2011:825), work discipline is a tool used by managers to communicate with employees so that they are willing to change a behavior.

According to Sutrisno (2013:86), discipline is an attitude of availability and a person's willingness to obey and obey the 
norms of the regulations that apply around him.

It can be concluded that discipline is the awareness and willingness of employees to follow the applicable regulations in the company and to follow the norms that apply at work.

\section{Employee Performance}

According to Wibowo (2014:104) suggests that performance is about doing work and the results achieved from the work. It takes an increase in the performance of each employee so that the goals can be achieved and can accelerate the work that has been set.

According to Umam (2012:186), performance is a record of the consequences generated on a job function or activity during a certain period related to organizational goals.

According to Kasmir (2016:182), performance is the result of work and behavior that has been achieved in completing the tasks and responsibilities given in a certain period.

It can be concluded that performance is the achievement of one's work seen from the completion of work, achievement of targets, and so on which are guided by norms, producer operational standards, criteria and measures that have been established or applicable in the organization.

\section{RESEARCH METHODS}

The approach used in this research is quantitative approach. Through this research, it is hoped that effect of leadership, motivation, and work discipline on employee performance at PT. Aneka Gas Industri Tbk., North Sumatra Region.

The total number of employees of PT. Aneka Gas Industri Tbk., North Sumatra Region is 310 people. The research time is planned from September-December 2020. The sampling technique in this study used simple random sampling using the slovin formula in determining the sample. The number of samples in this study was 175 people.
The data analysis model in this study is multiple linear regression analysis used to determine the effect of two or more independent variables $\left(\mathrm{X}_{1}, \mathrm{X}_{2}, \mathrm{X} 3\right)$ on the dependent variable (Y). Multiple linear regression analysis used $t$ test and $F$ test.

\section{RESULT}

\section{A General Description of the Company}

PT. Aneka Gas Industri Tbk. (AGI), is part of the Samator Group with a business base of being the first industrial gas company in Indonesia. Founded in 1916, AGI's main business is to supply industrial gases such as air gases (oxygen, nitrogen and argon), synthetic gases, fuel gases, rare gases, and sterilization gases, cooling gases (refrigerant gases) and electronic gases. AGI also supplies mixed, specialty and medical gases as well as equipment and installation services. AGI products have a wide range of applications and are used by a wide range of industries including medical, metallurgy, energy, infrastructure and others. AGI is currently listed on the Indonesia Stock Exchange as a public company. Along with the changes that occur in the current era of globalization, the implementation of development initiatives in the business world is not only carried out in terms of products and services to customers, but also in terms of social awareness which is considered to increase the company's "added value" for the local community.

As a form of corporate social responsibility program, the Company supports the development of small industries. Corporate social responsibility activities in this form have received the Upakarti award from the President of the Republic of Indonesia.

The Company continues to strive to increase "added value" for the benefit of the community. In the coming years, the company plans to be more proactive, with integrity and have a higher social awareness in order to present a corporate social responsibility program. 


\section{Descriptive Statistical Analysis}

The explanation of this analysis is to see the minimum, maximum, mean and standard deviation values in the number of respondents' answers being tested.

The results of the statistics will explain the value of the four variables tested in the descriptive statistical analysis, namely the variables of leadership, motivation, work discipline and performance.

The assessment can be seen for the leadership variable with a value of 175 respondents, the mean of 31.2286 with the smallest value of 19.00 and the largest value of 44.00 with a standard deviation of 6.89780 .

The assessment can be seen for the motivation variable with a value of 175 respondents, the mean of 31.7371 with the smallest value of 19.00 and the largest value of 45.00 with a standard deviation of 6.37340 .

The assessment can be seen for the work discipline variable with a sample of 175 respondents with a mean of 27.0743 with the smallest value of 17.00 and the largest value of 37.00 units with a standard deviation of 4.55997 .

The assessment can be seen for the employee performance variable with a sample of 175 respondents with a mean of 34.3429 with a minimum value of 21.00 and a maximum value of 46.00 units with a standard deviation of 5.01459 .

\section{Partial Hypothesis Testing (t Test)}

The $t$ test is used to determine whether there is a significant relationship or effect between the independent variables partially on the dependent variable.

\begin{tabular}{|c|c|c|c|c|c|c|}
\hline \multicolumn{7}{|c|}{ Coefficients $^{\mathbf{a}}$} \\
\hline \multirow{2}{*}{\multicolumn{2}{|c|}{ Model }} & \multicolumn{2}{|c|}{ Unstandardized Coefficients } & \multirow{2}{*}{$\begin{array}{c}\text { Standardized Coefficients } \\
\text { Beta }\end{array}$} & \multirow[t]{2}{*}{$\mathbf{t}$} & \multirow[t]{2}{*}{ Sig. } \\
\hline & & B & Std. Error & & & \\
\hline \multirow[t]{4}{*}{1} & (Constant) & 13.405 & 2.691 & & 4.982 & .000 \\
\hline & Leadership & .276 & .059 & .380 & 4.668 & .000 \\
\hline & Motivation & .179 & .065 & .227 & 2.747 & .007 \\
\hline & Work Discipline & .246 & .070 & .223 & 3.488 & .001 \\
\hline
\end{tabular}

The results showed partially, the leadership variable shows a positive and significant effect on employee performance at PT. Aneka Gas Industri Tbk., North Sumatra Region, motivation shows a positive and significant effect on employee performance at PT. Aneka Gas Industri Tbk., North Sumatra Region, work discipline shows a positive and significant effect on employee performance at PT. Aneka Gas Industri Tbk., North Sumatra Region.

\section{Simultaneous Hypothesis Testing (F Test)}

The F statistic test basically shows whether all the independent variables included in the model have a simultaneous effect on the dependent variable.

Table 2: F Test
\begin{tabular}{|l|l|l|l|l|c|c|}
\hline \multicolumn{2}{|c|}{ ANOVA $^{\mathbf{a}}$} \\
\hline \multirow{2}{*}{1} & Model & Sum of Squares & df & Mean Square & F & Sig. \\
\cline { 2 - 8 } & Regression & 1478.084 & 3 & 492.695 & 29.079 & $.000^{\text {b }}$ \\
\cline { 2 - 7 } & Residual & 2897.345 & 171 & 16.944 & & \\
\cline { 2 - 7 } & Total & 4375.429 & 174 & & & \\
\hline
\end{tabular}
a. Dependent Variable: Employee Performance
b. Predictors: (Constant), Leadership, Motivation, Work Discipline
Source: Research Results

In testing the data analysis simultaneously, the variables of leadership, motivation and work discipline shows a significant effect on employee performance at PT. Aneka Gas Industri Tbk., North Sumatra Region. 


\section{CONCLUSION AND SUGGESTION}

The results showed partially, the leadership variable shows a positive and significant effect on employee performance at PT. Aneka Gas Industri Tbk., North Sumatra Region, motivation shows a positive and significant effect on employee performance at PT. Aneka Gas Industri Tbk., North Sumatra Region, work discipline shows a positive and significant effect on employee performance at PT. Aneka Gas Industri Tbk., North Sumatra Region. In testing the data analysis simultaneously, the variables of leadership, motivation and work discipline shows a significant effect on employee performance at PT. Aneka Gas Industri Tbk., North Sumatra Region.

Useful suggestions for this research are

1. For Researchers

From the results of this study, it becomes the basis for looking at the influence of leadership, motivation and work discipline on employee performance.

2. For Companies

a. Provide a more familial leadership system with employees.

b. Provide motivation to employees in the form of salary increases or positions if they excel at work.

c. Tighten company regulations and impose sanctions in case of violation of work regulations by employees.

3. For the Faculty of Economics, Universitas Prima Indonesia

4. The results of this study become a model of the results of the study to conduct further research.

\section{Conflict of Interest: None}

\section{Source of Funding: None}

\section{REFERENCES}

1. Edison, Emron, Anwar, Yohny \& Komariyah, Imas. (2016). Manajemen Sumber Daya Manusia. Bandung: Penerbit Alfabeta.

2. Feriyanto, Andri \& Shyta, Endang Triana. (2015). Pengantar Manajemen. Kebumen: Mediatera.

3. Hasibuan, H. Malayu. (2014). Manajemen Sumber Daya Manusia. Jakarta: PT. Bumi Aksara.

4. Kasmir. (2016). Manajemen Sumber Daya Manusia (Teori dan Praktik). Depok: PT. Rajagrafindo Persada.

5. Nawawi. (2011). Manajemen Sumber Daya Manuisa: Untuk Bisnis yang Kompetitif. Yogyakarta: Gajah Mada University Press.

6. Rivai, Veithzal dan Sagala, Ella Jauvani. (2011). Manajemen Sumber Daya Manusia untuk Perusahaan. Jakarta: Rajawali Pers.

7. Sedarmayanti. (2014). Sumber Daya Manusia dan Produktivitas Kerja. Jakarta: Mandar Maju.

8. Sutrisno, Edy. (2013). Budaya Organisasi. Jakarta: Penerbit Kencana.

9. Umam, Khaerul. (2012). Manajemen Organisasi. Bandung: Pustaka.

10. Wibowo. (2014). Manajemen Kinerja. Jakarta: PT Rajagrafindo Persada.

11. Winardi. (2012). Manajemen Sumber Daya Manusia. Jakarta: Penerbit Rineka Cipta.

How to cite this article: Wiwin, Nazmi H, Febiola S et.al. Effect of leadership, motivation, and work discipline on employee performance at PT. Aneka Gas Industri Tbk., North Sumatra Region. International Journal of Research and Review. 2021; 8(7): 48-52. DOI: https://doi.org/ 10.52403/ijrr.20210709

Acknowledgement: None 